\title{
Fossil evidence for the evolution of the Casuarinaceae in response to low soil nutrients and a drying climate in Cenozoic Australia
}

\author{
RobertS. Hill (D) A, B, E, Sung Soo Whang ${ }^{\mathrm{C}}$, Vera Korasidis ${ }^{\mathrm{D}}$, Bradley Bianco ${ }^{\mathrm{A}}$, Kathryn E. Hill ${ }^{\mathrm{A}, \mathrm{B}}$, \\ Rosemary Paull $^{\mathrm{A}, \mathrm{B}}$ and Gregory R. Guerin ${ }^{\mathrm{A}}$

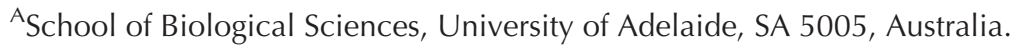 \\ ${ }^{B}$ Environment Institute, Benham Building, University of Adelaide, SA 5005, Australia. \\ ${ }^{C}$ Division of Science Education, Chonbuk National University, Jeonju 561-756, South Korea. \\ Department of Paleobiology, National Museum of Natural History, Smithsonian Institution, \\ Washington, DC 20013, USA. \\ ${ }^{\mathrm{E} C}$ Corresponding author. Email: bob.hill@adelaide.edu.au
}

\begin{abstract}
The Southern Hemisphere family Casuarinaceae has a long fossil record, both macrofossils and pollen, none of which provides any evidence about the morphology of the precursor to the family. However, it has long been considered, from both molecular phylogenies and morphological data, that the extant genus Gymnostoma retains key ancestral states and the highly reduced leaf area is a result of a scleromorphic response to low soil nutrients. Gymnostoma has by far the earliest, most extensive and best preserved macrofossil record, beginning in the Late Paleocene. Modification of the stomatal location from superficial in Gymnostoma to encrypted in furrows in the other genera assisted in water conservation as species evolved. We conclude that the morphology of the living and fossil vegetative branchlets provides evidence that low soil nutrients (especially phosphorus) and high water availability in a relatively light limited environment were the original drivers for evolution in the Casuarinaceae. Reducing water availability (xeromorphy) in progressively higher light environments were the major drivers of post-Eocene evolution in this unique plant family.
\end{abstract}

Received 24 July 2019, accepted 8 June 2020, published online 26 June 2020

\section{Introduction}

The fossil and living taxa of the angiosperm family Casuarinaceae exhibit evidence of a clear Gondwanan distribution with later, possibly extensive dispersal. Naturally occurring living members of the family are found mostly in south-east Asia, Malesia, Australia and the Melanesian and Polynesian regions of the Pacific, with concentrations of species in warm-temperate eastern and south-western Australia, and to a lesser extent, in the eastern regions of Malesia and New Caledonia (Johnson and Wilson 1989). Four extant genera are currently recognised - Gymnostoma, Ceuthostoma, Allocasuarina and Casuarina - containing 96 species (Johnson and Wilson 1989). The taxonomic affinities of the Casuarinaceae within the order Fagales have been the subject of much speculation. Hwang (1989) reviewed the older literature and concluded that there are two major schools of thought for the nearest affinities of the Casuarinaceae.

(1) The Betulaceae hypothesis: this emphasises the striking pollen similarity between the Casuarinaceae and Betulaceae (e.g. Erdtman 1966). However, Wodehouse
(1959) considered similarities between these two families to be due to convergence. Furthermore, Ueno (1963) found that the germ pores of pollen of the Betulaceae, Juglandaceae and Myricaceae can be stained with a 'papilla reaction' but those of Casuarinaceae cannot, leading him to conclude that the latter is distinct from the other families.

(2) The Hamamelidaceae hypothesis: this is based on floral and fruit morphology and concludes that Liquidambar 'cones' are probably the only homologous structures to Casuarinaceae 'cones' and particularly those of Gymnostoma (Hwang 1989).

Hwang (1989) concluded that the closest taxon to the Casuarinaceae does not readily fulfil the requirements for a 'good' phylogenetic outgroup, noting that the origin of the unique vegetative features of the Casuarinaceae are completely obscure.

More recent molecular phylogenies include the Ticodendraceae and Betulaceae as nearest living relatives. For example, Manos and Steele (1997), in their molecular study of the 'higher' hamamelids, placed Casuarinaceae in a clade with 
Betulaceae, Myricaceae and Ticodendraceae, and concluded that Betulaceae was the most likely sister taxon. This was supported by an $r b c \mathrm{~L}$ analysis of the Hamamelidae and their allies by Qiu et al. (1998). Xiang et al. (2014) noted the likely diversification of the Casuarinaceae at c. 56.2 million years ago (range: 45.2-65.7 Ma), with its closest extant relatives being the Betulaceae and Ticodendraceae. However, Steane et al. (2003), in support of Hwang (1989) concluded that the highly distinct morphology of the Casuarinaceae, i.e. its articulate branchlets, reduced and fused leaf lamina and whorled inflorescence structure, makes morphological comparison with other groups especially difficult. Furthermore, the fossil pollen record can only be resolved to family level and the macrofossil record, while extensive, only contains specimens that can be assigned to an extant genus unless key morphological evidence is lacking. Thus, there is currently no conclusive morphological evidence for the evolutionary transition that led to this family from the living or fossil record.

The vegetative morphology of the Casuarinaceae has been used to explain how low soil nutrients, and especially phosphorus, can influence the vegetative structure of a taxon (scleromorphy) and that later exposure to a drying climate results in xeromorphy (Hill 1990, 1994, 1998; Hill and Brodribb 2001; Dörken and Parsons 2017; Dörken et al. 2018, 2019). Recent research has added significant evidence for this hypothesis and the number of relevant fossils has also increased substantially. The purpose of this paper is to examine the evidence for the origin of the unique vegetative morphology of the Casuarinaceae, along with the likely impact of low soil nutrients, relatively low light levels and then reduced water availability, on the evolution of vegetative structures within this family.

\section{Material and methods}

Most of the material used for this study was already in the existing fossil and living collections held in the David T. Blackburn Palaeobotany Collection at the University of Adelaide. Many different approaches were made to preparation of these specimens. The Stuart Creek branchlets exist as moulds in the silcrete. Silicone casts were made of these using Oranwash L c-silicone impression material (Zhermack Clinical, Badia Polesine, Italy).

These moulds and some branchlets of extant species were examined with an Auto-montage Research Stereomicroscope (Nikon SMZ 25, Tokyo, Japan). Images were produced using an automatic stacking system in NIS-Elements AR imaging software (ver. 4.60, NIS, Nikon). All scanning electron images were obtained as part of previous research projects. Light microscope images of the cuticles of living species were taken using an Olympus BX53 photomicroscope (Tokyo, Japan).

\section{The vegetative morphology of Casuarinaceae}

According to Johnson and Wilson (1989) all living species of Casuarinaceae have 'distinctive slender wiry articulate branchlets, with the leaf lamina reduced to small teeth in a whorl surrounding the summit of each article of the branchlet'. They also note that Gymnostoma and Ceuthostoma and the juvenile plants of Allocasuarina and Casuarina have four teeth per whorl (see also Dörken and Parsons 2017; Dörken et al. 2018), but for adult plants of Allocasuarina species these vary from four to 15 teeth per whorl and for Casuarina species, from 5 to $\sim 20$ teeth per whorl. Flores (1980) concluded that the juvenile foliage of the species she examined (from three genera) existed in pseudowhorls, whereas the mature foliage is in true whorls. However, Johnson and Wilson (1989) dismissed Flores' evidence for pseudowhorls as 'unnecessarily complex' and categorically stated that no Casuarinaceae are pseudoverticillate. No further detailed examination of the origin of the leaf whorls in Casuarinaceae has been published. Flores (1980) also concluded that the whorled phyllotaxy in Casuarinaceae was derived from a former helical arrangement and that the evolutionary mechanisms primarily involved have been alterations to internodal lengths and the angles of leaf divergences. Given that no other angiosperm taxon has leaves in true whorls of four or more, this interesting observation deserves further examination.

Flores (1980) also noted that the entire vegetative node of a Casuarinaceae branchlet consists of fused leaves, with just the tips of the leaves (=teeth) being free from fusion (i.e. the entire article in Fig. 1 consists of fused leaves). Dörken and Parsons (2017) also noted that in Casuarinaceae shoots are 'clothed by leaf tissue', a conclusion that they note conflicts with some published accounts where Casuarinaceae shoots are referred to as cylindric cladodes (e.g. Rao 1972; Zimpfer et al. 2004; Niinemets et al. 2005), photosynthetic branchlets with highly reduced leaves (Torrey and Berg 1988) and phylloclades (Warrier et al. 2013). Johnson and Wilson (1989) considered the teeth to be the leaf blade, with the remainder of the photosynthetic tissue below the teeth representing a fused and elongated leaf base. Our interpretation of the furrows that often occur on the photosynthetic stems of Casuarinaceae is that they represent the line where two

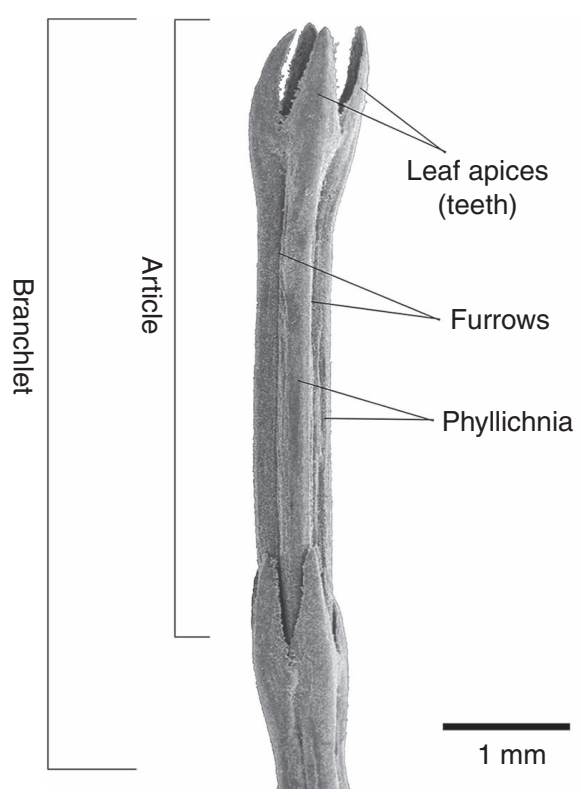

Fig. 1. Scanning electron micrograph of part of a photosynthetic branchlet of Gymnostoma rumphianum with the major morphological terminology applied. 
adjacent leaves have fused and the teeth represent unfused leaf tips. The distinction between the end of the leaf base and the beginning of the leaf blade is now probably impossible to determine.

A unique terminology has developed to explain the vegetative structure of the Casuarinaceae (Fig. 1), with the fused part of the leaves being called phyllichnia. Johnson and Wilson (1989) define phyllichnia as the ridges on the articles. However, Dörken et al. (2018) conclude that this is an external expression of the anatomy of the structures and they suggest that the term be used for the whole of what is now the fused part of the leaf. The remaining terminology in Fig. 1 is less contentious.

Stomata generally occur in bands that run parallel to the long axis of the article. In Ceuthostoma, Allocasuarina and Casuarina, stomatal bands are restricted to the pronounced furrows between the fused leaves (Fig. $2 a, b, f, h, i$ ), except in the juvenile, four-leaved stage, when stomatal bands are not encrypted (Dörken and Parsons 2017; Dörken et al. 2018). As part of this study, we noted that in some Ceuthostoma specimens occasional stomata occur on the teeth. In Gymnostoma, stomatal bands occur along the fused portions of the leaf margins, occasionally extending on to the free portion of the leaves (Christophel 1980; Fig. 2c-e, g). Sometimes these bands remain separated from the leaf apex down the length of the article (Fig. $2 c, d$ ), but sometimes they fuse just below the teeth into a single band (Fig. 2e).

Phylogenetic analyses of Casuarinaceae (e.g. Sogo et al. 2001; Steane et al. 2003) support the conclusion that Gymnostoma morphology is closest to the ancestral type for the family, as does the extensive morphological research by Dörken and Parsons (2017) and Dörken et al. (2018, 2019). This research supports Hill's hypothesis (Hill 1990, 1994, 1998; Hill and Brodribb 2001) that Gymnostoma represents a taxon that initially evolved in response to low soil phosphorus, and thus exhibits quite extreme scleromorphic characteristics. Later, as climates became increasingly dry and eventually arid, the genera Ceuthostoma, Allocasuarina and Casuarina probably enhanced their capacity to survive by utilising their scleromorphic adaptations as exaptations in response to increasing xeromorphic conditions. A detailed examination of both living and fossil branchlets of Casuarinaceae now allows for a more thorough assessment of the directions that Casuarinaceae branchlet evolution may have taken under changing external selection pressures.

\section{Morphological variation in extant Casuarinaceae branchlets}

Gymnostoma branchlets are uniformly four-parted and are often referred to as being uniform in cross-sectional shape. For example, Christophel (1980) states that all species have completely uniform branchlets that have a tetrahedral cross section. We presume that he intended this to be 'square', since 'tetrahedral' refers to a three dimensional shape. However, close examination of the living species shows that the articles that compose the branchlets are quite variable in shape, and especially in cross section. Some extant Gymnostoma species have a well-developed furrow running the length of the article (Fig. $3 a, b, 4 a$ ), but, in contrast to other genera, the stomates are not within this furrow (Fig. 4a). Other Gymnostoma species have stems that are more or less square in cross section, with no furrow (Fig. 3c). A third shape involves the space between the phyllichnia forming into a relatively deep depression that is more or less uniform in shape between adjacent phyllichnia and produces a highly characteristic sectional shape (Fig. $3 d-f, 4 b$ ). Although this may be exaggerated due to drying of the specimen, it is clear that this reflects the shape during life (Fig. 4b). Some species appear to be highly variable, with some specimens having articles with well-developed furrows, whereas others have no furrow at all, and at a higher taxonomic level the distribution of furrows follows no apparent geographic or taxonomic pattern within the genus.

Ceuthostoma species also have teeth in whorls of four, with well-developed furrows between the phyllichnia. Unlike Gymnostoma, the stomatal bands are placed deep within these furrows, which are also filled with trichomes (Fig. $2 a$, 4c). Allocasuarina and Casuarina species have a highly variable number of teeth per whorl, and also have well developed, trichome-filled furrows between phyllichnia (Fig. $4 d, e$ ), which contain stomatal bands (Fig. $2 b, f, h, i$ ).

Flores (1977) noted that changes in stomatal and trichome morphology are climate dependent, i.e. Gymnostoma is essentially glabrous or almost glabrous, whereas the other Casuarinaceae species she examined were conspicuously pubescent. She also noted that Morini (1895) reported trichomes in G. chamaecyparis (Poiss.) L.A.S.Johnson, but that they are scarce, unicellular and restricted to the slight furrows found between two contiguous leaves. Scriven and Christophel (1990) reported unicellular trichomes on the articles of at least 11 extant Gymnostoma species, but they are generally sparse. By contrast, trichomes in the other species examined by Flores (1977) (belonging to Allocasuarina and Casuarina) were unicellular or multicellular and both branched or unbranched. Some of the species were highly pubescent, but others only moderately so. Flores also reported that trichomes are mostly restricted to the furrows and the leaf blade margins, although in some species (e.g. C. stricta) they are abundant on the surface of the article.

Our examination of extant Casuarinaceae species reinforces the general trends reported in the literature. Sparse trichomes were observed in the base of the furrow in some Gymnostoma species (e.g. Fig. 2g), whereas others were glabrous (Fig. $2 c-e$ ). In some species (e.g. Ceuthostoma palawanense L.A.S.Johnson and Allocasuarina torulosa (Aiton.) L.A.S.Johnson, Fig. $2 a, b$ ) trichomes are abundant on the margins of teeth and in the furrows, suggesting that all these trichomes may have originated on the leaf margins before fusion. In Gymnostoma, the margins of the teeth consist of distinctive cells, but these are not obviously trichomes (Fig. 2c, d). If Gymnostoma is the closest genus to the ancestral form in Casuarinaceae, then trichomes were probably sparse in early members of this family and evolved to greater density and complexity in response to later selection pressures.

Morphological variation in fossil Casuarinaceae branchlets Well-preserved Casuarinaceae branchlets are available from many Cenozoic sites in Australia (Fig. 5; Table 1). Although 


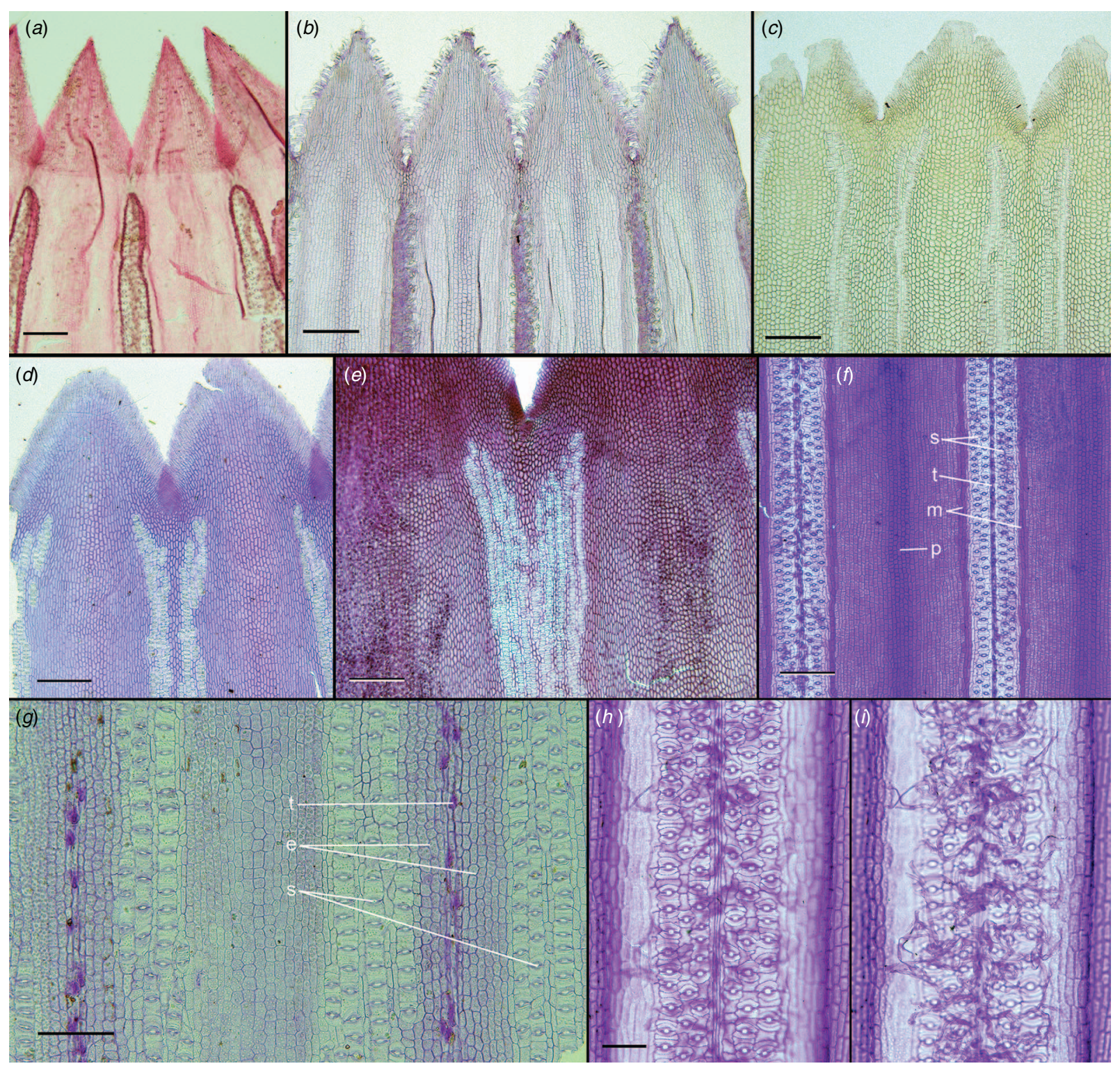

Fig. 2. Light microscope images of the cuticle from articles and teeth of living Casuarinaceae species. (a) Ceuthostomata palawanense showing the four teeth, each with a few isolated stomata, trichomes on the margins of the teeth, and stomata in deep furrows that begin just below the teeth. These furrows also contain densely packed trichomes. Scale bar: $200 \mu \mathrm{m}$. (b) Allocasuarina torulosa, showing the four teeth, with no stomata present, but with multicellular trichomes prominent on the margins. Stomata are restricted to furrows that begin just below the teeth, but are difficult to observe, because the furrows contain densely packed trichomes that look like they may be extensions of the trichomes on the margins of the teeth. Scale bar: $200 \mu \mathrm{m}$. (c) Gymnostoma leucodon showing three of the four teeth, with stomata ending near the base of each tooth. The cells on the margins of the teeth appear to be specialised, but they are not trichomes. Stomata occur in two bands, commencing on either side of each tooth, so that there are eight bands of stomata on each article, each of which shows as a pale vertical line. There is no evidence of a furrow between the phyllichnia and the stomatal bands are fully exposed on the surface of the article. Trichomes are absent. Scale bar: $200 \mu \mathrm{m}$. (d) Gymnostoma webbianum showing two of the four teeth, with highly modified cells on the tooth margins. Stomata are in bands, but they are separated from those on adjacent phyllichnia by fewer cells than in $G$. leucodon (c). Furrows and trichomes are both absent. Scale bar: $200 \mu \mathrm{m}$. (e) Gymnostoma deplancheanum showing the point where two adjacent teeth meet and the rows of stomata that begin at the base of each tooth but merge into a single band just below the teeth. Furrows and trichomes are absent. Scale bar: $200 \mu \mathrm{m}$. (f) Allocasuarina torulosa, part of the surface of an article, showing two furrows that have been flattened out on the slide, so that each can be seen to consist of a band of stomates (s) on either side of a row of trichomes $(\mathrm{t})$, which occur at the base of the furrow. The furrow margins (m) are marked by cells that are stained slightly darker than those on the exposed phyllichnia. The mid line of one phyllichnium is marked (p). Scale bar: $200 \mu \mathrm{m}$. ( $g$ ) Gymnostoma rumphianum showing two stomatal furrows on part of an article. The furrows have dark staining trichome bases at the deepest point $(\mathrm{t})$, flanked by bands of epidermal cells (e) that make up the rest of the furrow. The stomatal bands (s) are not within the furrow, they are on the exposed surface of the phyllinchnium. Scale bar: $100 \mu \mathrm{m}$. $(h, i)$ Allocasuarina muelleriana showing the detail of a furrow at two different focal planes. In $(h)$ the stomatal bands can be seen either side of the base of the furrow, whereas in $(i)$ the focus is on the dense, branched trichomes that fill the furrows. Scale bar for both: $50 \mu \mathrm{m}$. 


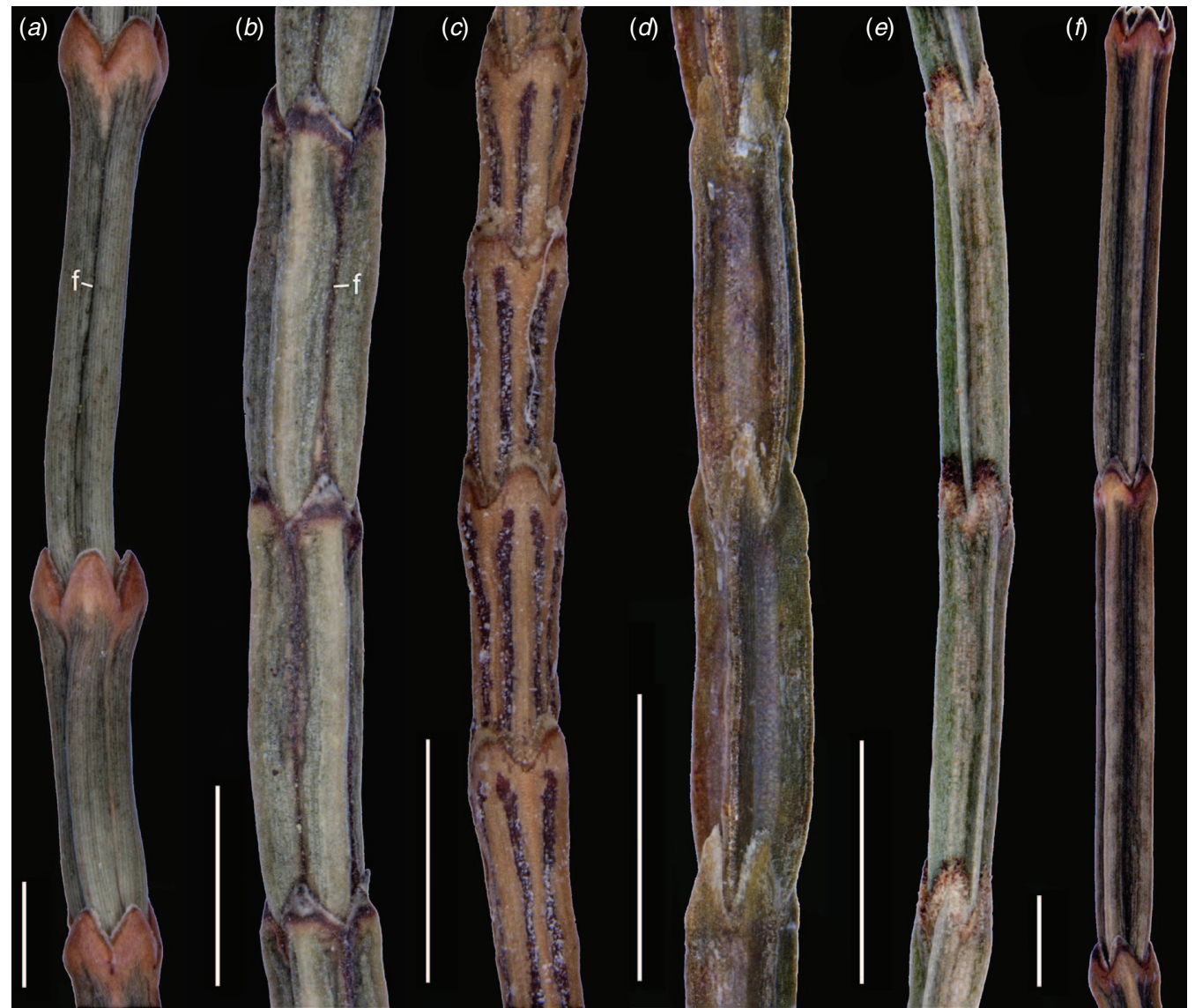

Fig. 3. Images of sections of branchlets containing at least two complete articles from six extant Gymnostoma species. Images were taken using an Auto-montage research stereomicroscope (Nikon SMZ 25, Tokyo, Japan). (a) Gymnostoma glaucescens, (b) Gymnostoma webbianum, (c) Gymnostoma leucodon, $(d)$ Gymnostoma australianum, (e) Gymnostoma sumatranum, $(f)$ Gymnostoma deplancheanum. Scale bars: $1 \mathrm{~mm}$. In $(a)$ and $(b)$ there are distinct furrows between the phyllichnia (marked f) but the stomatal bands are exposed and finish near the edges of the furrows. The articles are square in section, but with rounded phyllichnia. The shape of the section in these phyllichnia is shown in Fig. $4 a$. In $(c)$ there is no furrow between phyllichnia and the stomatal bands are clearly visible as a pair of dark bands running parallel down each phyllichnium. The article is square in section. In $(d-f)$ there is no furrow, but the surface of the article is deeply curved inwards between each pair of phyllichnia. The stomata are in two rows per phyllichnium. The shape of the section in these phyllichnia is shown in Fig. $4 b$.

most of these are species of Gymnostoma, specimens of other genera are also present. Amongst the Gymnostoma fossils, many have articles with well-developed furrows and phyllichnia that are individually rounded in shape (e.g. Fig. $6 a-f, 7 a, b)$. However, some have a more angular appearance and the phyllichnia have a sharp apex and a straight lamina towards the furrow (Fig. $6 g, h, 7 c$ and possibly Fig. 6i). A few specimens have no obvious furrow and are approaching a square-shaped section (Fig. $7 d, e$ ). Amongst the fossil branchlets that do not belong to Gymnostoma, the most informative is Cryptostomiforma quinata G.R. Guerin \& R.S. Hill from Riversleigh (Guerin and Hill 2006). This species is not placed in an extant genus because it is impossible to place the vegetative fossils in one of either Casuarina or Allocasuarina. The articles were reported as having five teeth per whorl (Fig. $8 a, b, d$ ) and deeply developed furrows containing the stomates in bands well inside the furrow (Fig. $8 e-g$ ). However, recently some specimens have been observed that may contain only four teeth per whorl (Fig. 8c), reinforcing the possibility that four teeth per article is ancestral in Casuarinaceae. A combination of four and five teeth per whorl is within the range of extant Allocasuarina, but not Casuarina. However, a more refined generic identity of these fossils cannot be determined in the absence of fossils of reproductive structures.

Although trichomes have been reported as absent from some described fossil Gymnostoma species (e.g. Scriven and Hill 1995; Guerin and Hill 2003), some undescribed fossil Gymnostoma articles do appear to have trichome bases in the furrows. The extent and type of trichomes in fossil Gymnostoma will require a more detailed investigation, since cuticle with preserved trichomes is often difficult to retrieve from fossil articles. Guerin and Hill (2006) reported common trichomes in the furrows on the articles of Crytpostomiforma quinata and trichome bases (Fig. 8f) and branching trichomes (Fig. $8 g$ ) are clearly visible on the 


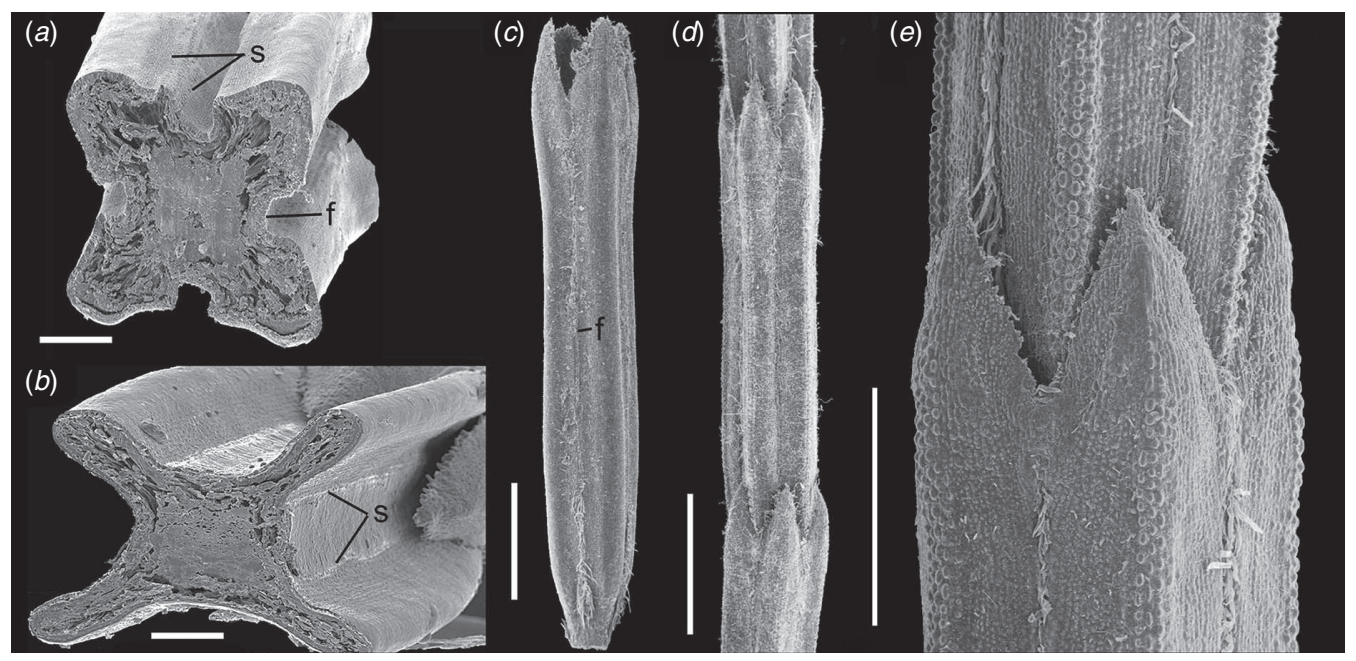

Fig. 4. Scanning electron micrographs of articles of extant Casuarinaceae. (a) Gymnostoma glaucescens showing a section of an article, with the relatively deep furrow (f) between each pair of phyllichnia and stomatal bands (the width of one band is marked as s) on the exposed part of the phyllichnia and just overlapping into the furrow. Scale bar: $200 \mu \mathrm{m}$. (b) Gymnostoma australianum showing that the surface of the article is deeply curved inwards between each pair of phyllichnia. The stomatal bands occur in the deepest part of the flattened section. The position of the two adjacent stomatal bands is marked (s). Scale bar: $100 \mu \mathrm{m}$. (c) Ceuthostoma terminale showing a complete article. Deep, trichome-filled furrows (f) occur between each pair of phyllichnia and the bands of stomata are enclosed within these furrows (see Fig. $2 a$ for the other species of Ceuthostoma). Scale bar: 1 mm. (d) Allocasuarina torulosa showing a complete article. The general form of this article is similar to that shown in $(c)$, except that there are five teeth per whorl instead of four. Scale bar: $1 \mathrm{~mm}$. (e) Allocasuarina muelleriana showing the apex of one article and the base of the next one, with the whorl of teeth in between. The trichome filled furrows between the phyllichnia are clearly visible and the stomatal rows are within these. Scale bar: $500 \mu \mathrm{m}$.

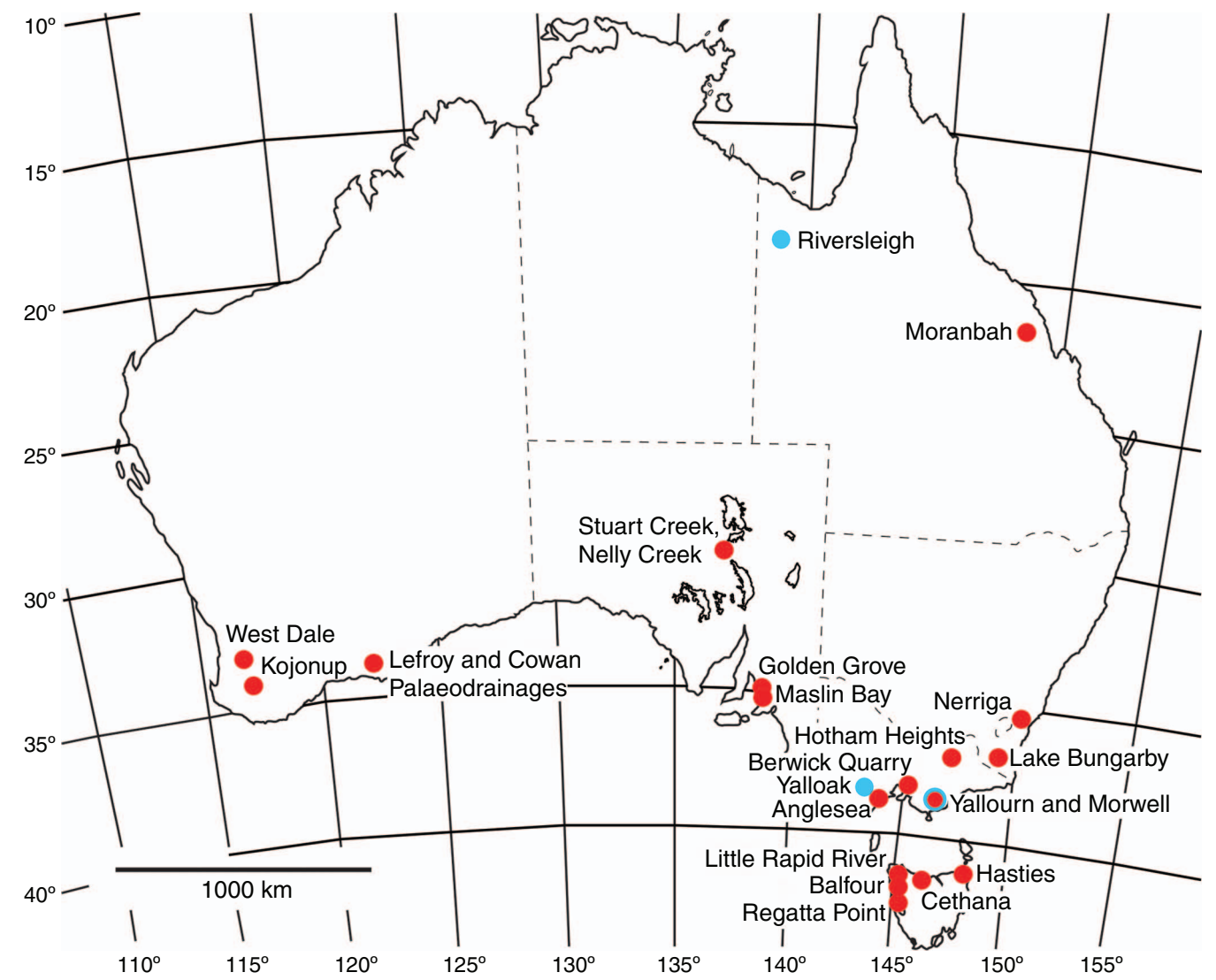

Fig. 5. Map of Australia showing the localities where vegetative macrofossil remains of Gymnostoma (red circles) or non-Gymnostoma taxa (light blue circles) have been found. Dispersed cuticle records have only been included where this distinction between genera can be made. A full record of these localities is shown in Table 1 . 
Table 1. List of pre-Quaternary macrofossil records of vegetative remains of Casuarinaceae in Australia where the generic identity is reasonably well established

\begin{tabular}{|c|c|c|}
\hline Location & Age & References \\
\hline \multicolumn{3}{|c|}{ Gymnostoma } \\
\hline Lake Bungarby & Late Paleocene & Scriven and Hill (1995) \\
\hline Regatta Point & Early Eocene & Hill (1990), Pole (1998) \\
\hline Hotham Heights & Early-Mid Eocene & $\begin{array}{l}\text { Douglas (1978), Christophel (1980), } \\
\text { Carpenter et al. (2004) }\end{array}$ \\
\hline Anglesea & Late Middle Eocene & $\begin{array}{l}\text { Christophel (1980), } \\
\text { Scriven and Christophel (1990) }\end{array}$ \\
\hline Maslin Bay & Middle Eocene & Lange (1970), Christophel (1980) \\
\hline Golden Grove & Middle Eocene & Christophel and Greenwood (1987) \\
\hline Nerriga & Middle Eocene & Christophel (1980), Hill (1982) \\
\hline Nelly Creek & Middle Eocene & Christophel et al. (1992) \\
\hline Hasties & Middle-Late Eocene & Pole (1992) \\
\hline Little Rapid River & Early Oligocene & Hill (1990), Guerin and Hill (2003) \\
\hline Cethana & Early Oligocene & Hill (1990) \\
\hline Yallourn and Morwell & Miocene & Christophel (1980), \\
\hline Berwick Quarry & Late Oligocene-earliest Miocene & $\begin{array}{l}\text { Pole et al. (1993), D. T. Blackburn } \\
\quad \text { (unpubl. data) }\end{array}$ \\
\hline Stuart Creek & Early Miocene-Early Pliocene & Callen (2020) \\
\hline Moranbah & Eocene & Scriven and Christophel (1990) \\
\hline West Dale & Middle Eocene-Oligocene & Hill and Merrifield (1993) \\
\hline Kojonup & Late Eocene & McLoughlin and Hill (1996) \\
\hline Lefroy and Cowan Palaeodrainages & Late Middle Eocene & Carpenter and Pole (1995) \\
\hline Balfour & Oligocene-Early Miocene & Hill (2001) \\
\hline \multicolumn{3}{|c|}{ Non-Gymnostoma } \\
\hline Riversleigh & Oligocene & Guerin and Hill (2006) \\
\hline Yallourn and Morwell & Miocene & D. T. Blackburn (unpubl. data) \\
\hline Yalloak & Miocene & Patton (1936) \\
\hline
\end{tabular}

fossils, and these closely resemble those illustrated by Burrows (2001, his fig. 1G) for Allocasuarina verticillata, which he calls 'Y-shaped'.

An important resource for the palaeobotany of the Latrobe Valley coals is an unpublished report by Dr D. T. Blackburn, which was prepared for the State Electricity Commission of Victoria, Fuel Department in 1985. Although that report is not generally available, it is referred to here because it is the only source of some key information. Blackburn (unpubl. data) described glabrous Gymnostoma articles and female cones from the Morwell Open Cut Coal Mine and earlier Pike (1953) described a Casuarinaceae cone from the Yallourn Open Cut Coal Mine that appears from the illustration to belong to Gymnostoma. Blackburn (unpubl. data) also reported and illustrated non-Gymnostoma Casuarinaceae articles from both Morwell and Yallourn. He identified the Early Miocene as Casuarina and not Allocasuarina, even though they have only four teeth per whorl, which occurs in some extant Allocasuarina, but not Casuarina. He noted that common trichome bases are present on these fossils and he also illustrates abundant unbranched trichomes in the base of the furrows, on the margins of the teeth and on the exposed surface of the phyllichnia. This is the only fossil location where Gymnostoma has been found in conjunction with another Casuarinaceae genus, even though in this complex location there is no evidence that they co-occurred in the same vegetation types.
Given the lack of reproductive fossils, and especially female cones, it is possible that both of these nonGymnostoma macrofossil records could represent an extinct genus, but that is not significant in explaining the overall evolution of the vegetative organs within this family.

\section{Possible evolutionary pathways for the foliage of Casuarinaceae}

Although we have no direct evidence for the conditions leading to the evolution of the Casuarinaceae, the recent description of fragmentary but well preserved leaf fragments from Late Cretaceous sediments in central Australia (Carpenter et al. 2015) provides evidence for a Proteaceae-dominated, open and frequently-burnt sclerophyll vegetation containing taxa with strong morphological resemblance to living genera. The Casuarinaceae were not recorded at this locality, and indeed may not yet have been in place, given that the oldest record of the family is Late Cretaceous pollen recorded from the Capricorn Basin off the central Queensland coast (Hekel 1972) that Dettmann (1994) regards as being of questionable age. The unequivocal pollen record of the family begins in Australia in the Paleocene (Macphail et al. 1994). Nevertheless, the Late Cretaceous environment described by Carpenter et al. (2015) provides a model for the environment that may have led to the evolution of the Casuarinaceae and they consider the 


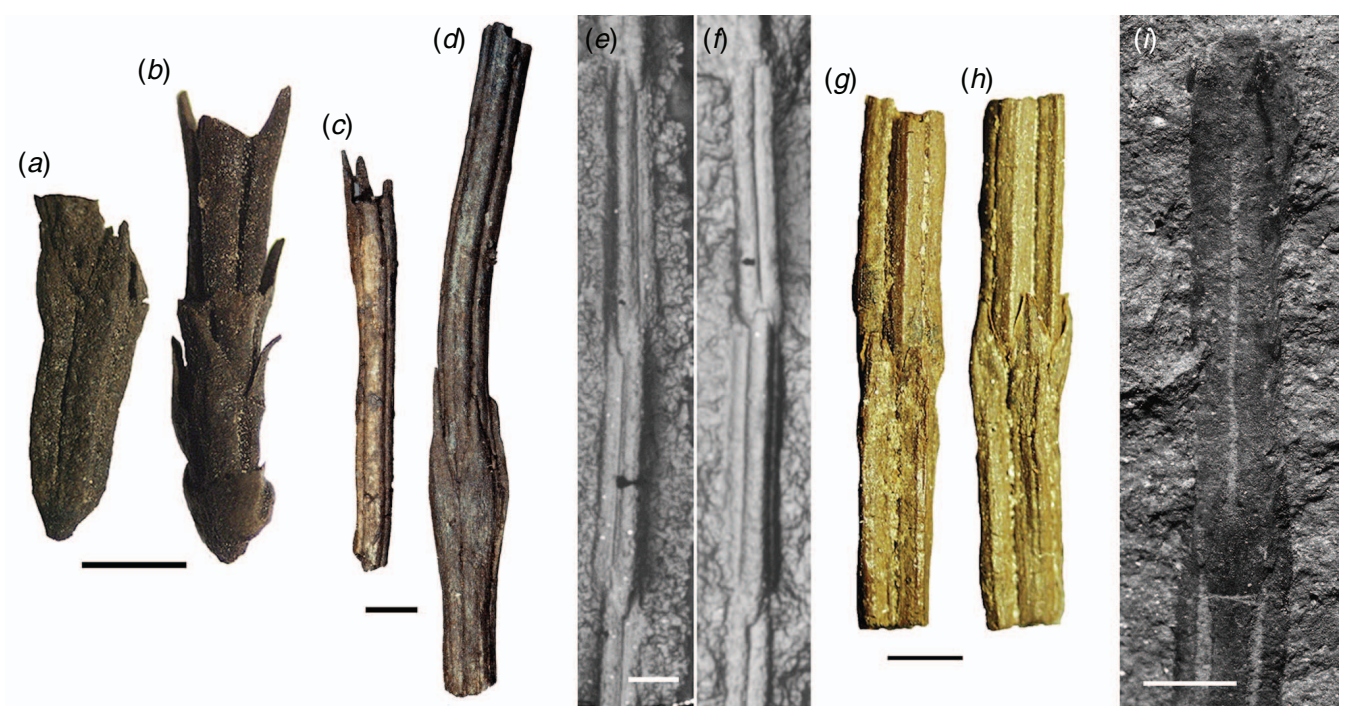

Fig. 6. Light microscope images of sections of branchlets of undescribed species of fossil Gymnostoma, all of which contain deep furrows between adjacent phyllichnia $(a, b)$ Balfour. Scale bar: $1 \mathrm{~mm} .(c, d)$ Yallourn and Morwell. Scale: $1 \mathrm{~mm}$. $(e, f)$ Silicon casts of branchlets from Stuart Creek. Scale bar: $1 \mathrm{~mm}$. $(g, h)$ Nelly Creek. Scale bar: $500 \mu \mathrm{m}$. (i) West Dale, the light band represents the position of the deep furrow between adjacent phyllichnia. Scale bar: $1 \mathrm{~mm}$.

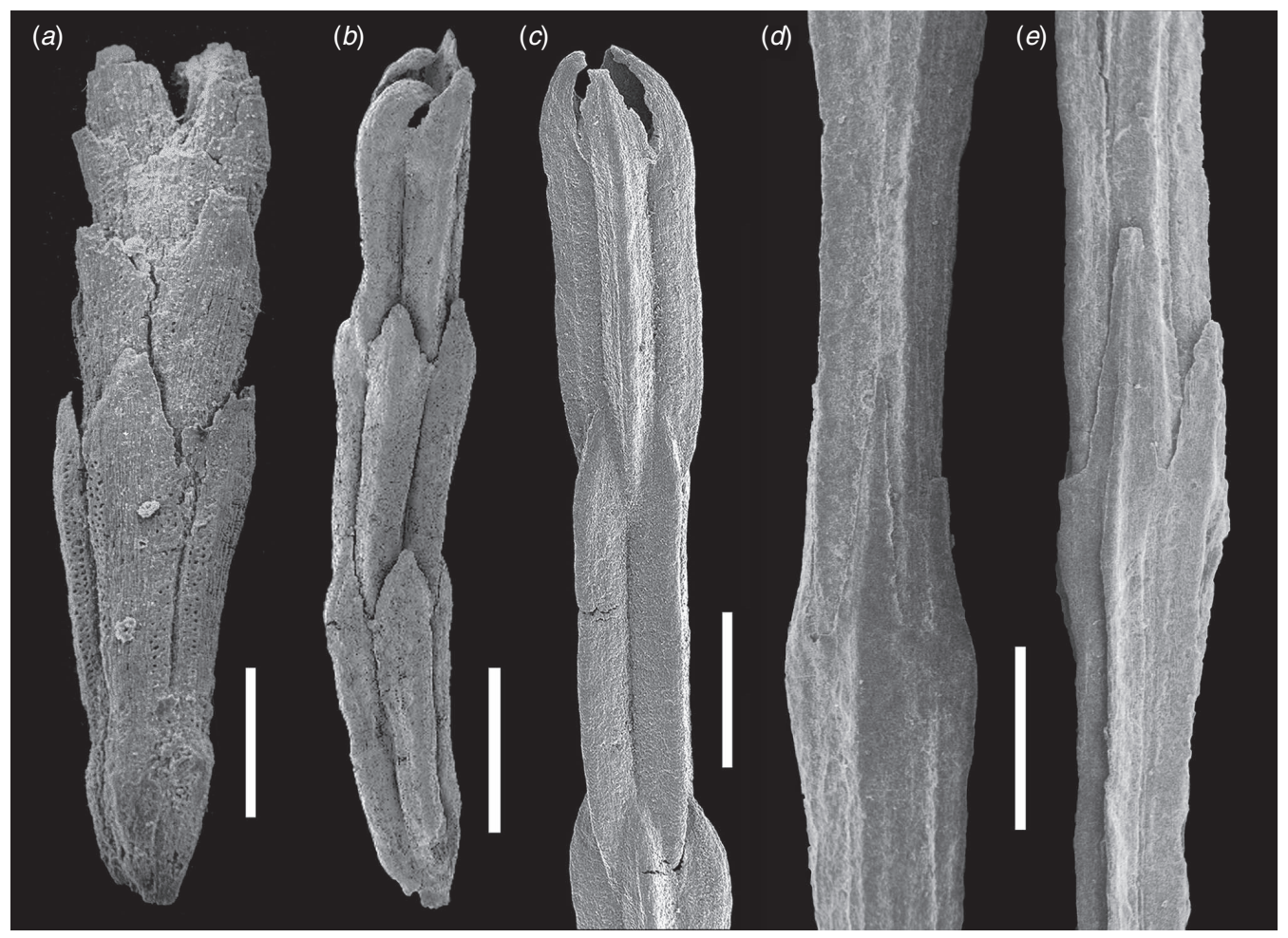

Fig. 7. Scanning electron micrographs of sections of branchlets of fossil Gymnostoma species. (a) Regatta Point, note the deep furrow between adjacent phyllichnia. The stomatal bands next to these furrows are also clearly visible in the basal article. Scale bar: $500 \mu \mathrm{m}$. (b) Balfour, note the deep furrow between adjacent phyllichnia. Scale bar: $1 \mathrm{~mm}$. (c) Gymnostoma tasmanianum G.R. Guerin \& R.S. Hill from Little Rapid River (Guerin and Hill 2003). The phyllichnia have almost straight sides that lead down to a shallow furrow. Scale bar: $500 \mu m$. $(d, e)$ Anglesea, note the much more square shape of the article. Grooves between phyllichnia are shallow or absent. Scale bar: $1 \mathrm{~mm}$. 


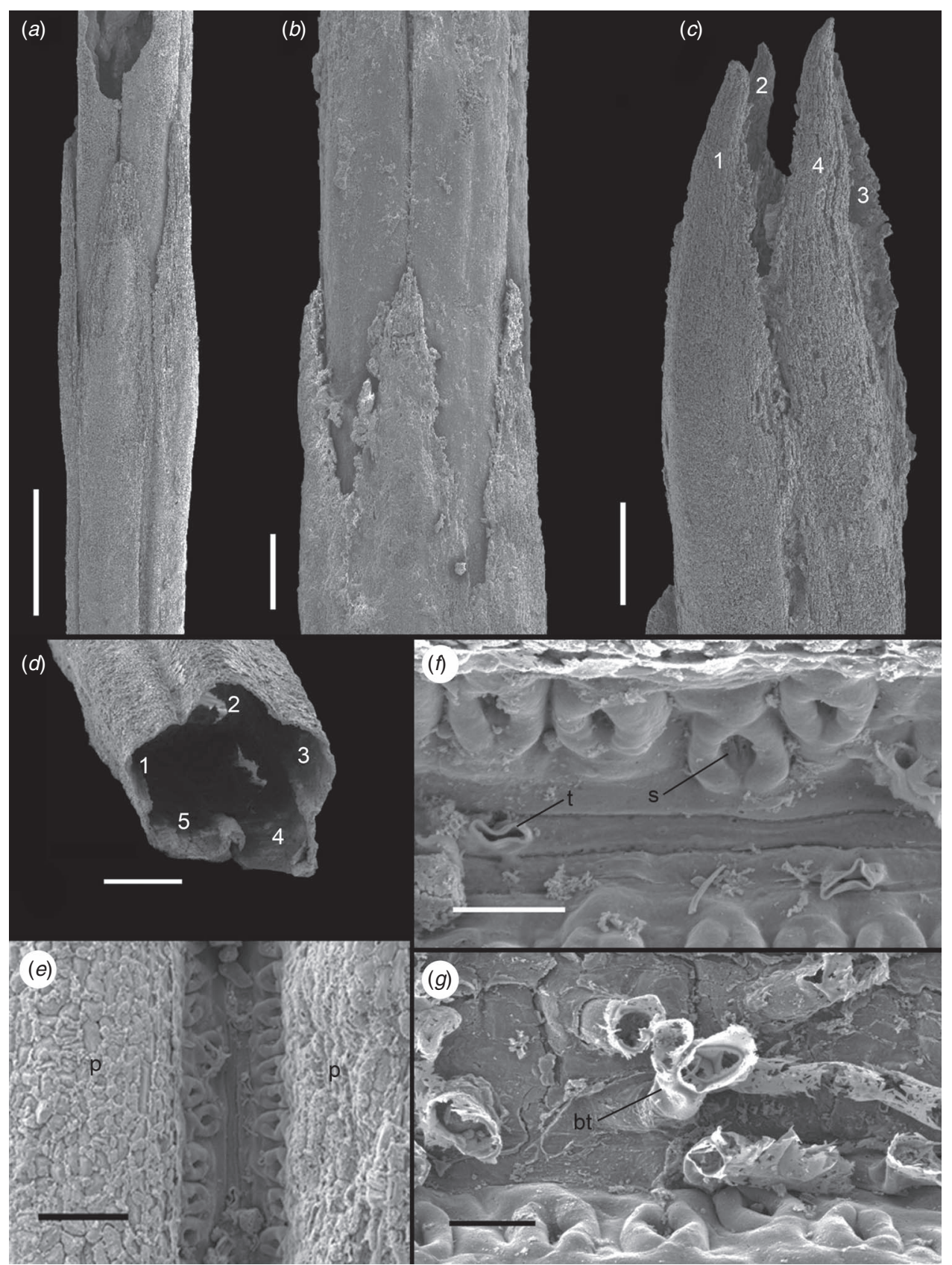

Fig. 8. Scanning electron micrographs of Cryptostomiforma quinata (Guerin and Hill 2006). (a) Part of a branchlet showing three of the five teeth in a whorl and the furrows between adjacent phyllichnia. Scale bar: $500 \mu \mathrm{m}$. (b) Three teeth from a whorl of five, with the furrow between adjacent phyllichnia clearly visible above the middle tooth. Scale bar: $200 \mu \mathrm{m}$. (c) The apex of an article showing a whorl of four teeth, numbered 1-4. Scale bar: 200 $\mu \mathrm{m}$. (d) Section of an article, with only the cuticle preserved. Five phyllichnia are clearly visible (numbered 1-5), along with furrows of varying depths. Scale bar: $200 \mu \mathrm{m}$. (e) The interior of a furrow. The bands of stomata can be seen on each side of the furrow, with the margins of the adjacent phyllichnia (p) on either side. Scale bar: $50 \mu \mathrm{m}$. (f) Close-up view into a furrow, with two trichome bases visible at the bottom of the furrow (one labelled t), with a band of stomata visible above on the furrow wall (one stoma is labelled s). Scale bar: $20 \mu \mathrm{m}$. (g) The base of a furrow, with some trichome remnants visible. One of the trichomes has branched (bt). Scale bar: $20 \mu \mathrm{m}$.

Maquis vegetation of New Caledonia to be a possible modern analogue of this.

We do not know the form of the first members of the Casuarinaceae, but it is clear from the macrofossil record that Gymnostoma was in place by the Late Paleocene
(Scriven and Hill 1995) and so the following discussion is based on this. It is now generally accepted that Gymnostoma today has an ecological niche that is dominated by monospecific stands in relatively high-light areas, with seedlings occurring abundantly under the mature canopy 


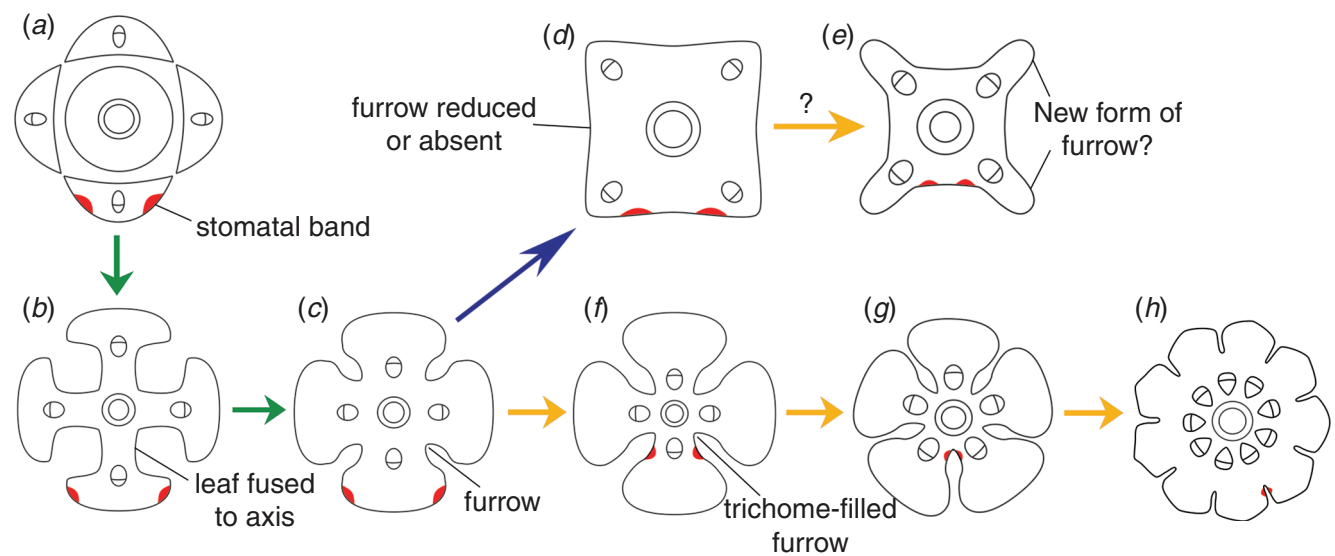

Fig. 9. Summary diagram of the possible evolution of foliage within the Casuarinaceae. The emphasis is on the fusion of leaves, the external shape of the article in transverse section, and the position of stomata and trichomes. Other details are highly stylized. The position of stomatal bands is shown in red. Green arrows represent a scleromorphic response, the blue arrow a response to increased water availability and deeper shade, and the orange arrows represent a xeromorphic response. This is the simplest model we could devise, as other pathways may remain to be discovered. (a) Hypothetical ancestor, with a main stem and four leaves closely appressed but free to their base. These leaves have their stomata in two bands on either side of the mid-vein, on the abaxial (outer) leaf surface. They probably evolved small, elongate leaves in response to low nutrient, and especially low phosphorus, soils (scleromorphy). (b) In the first step, these leaves fuse to the main stem on the adaxial surface. This fusion presumably occurred for almost the entire length of the leaves, leaving only the tips free ('teeth' in extant Casuarinaceae). (c) With further fusion, this becomes the original Gymnostoma, which dates to the Late Paleocene, with leaves fused to the main stem, a furrow between each pair of fused leaves (phyllichnia), and a band of stomata each side of the vein on the original abaxial (outer) leaf surface. The furrows have few, if any trichomes present. $(d)$ In the extremely wet conditions that characterised at least parts of Australia during the Eocene, some Gymnostoma species lost the furrow between phyllichnia in an attempt to maximise the available photosynthetic area in the wet and shady environments where these species grew. This appears to have evolved at least twice within Gymnostoma. (e) As the Gymnostoma species with no furrows experienced drying conditions in Australia from the Oligocene onwards, they evolved to increase the boundary layer above their stomata. Because the furrows had disappeared in these species, they instead developed a single large depression between the apices of the phyllichnia, with the stomatal bands occurring in the deepest parts of these depressions. This is a xeromorphic response and is especially well developed in extant G. australianum. $(f)$ As some Gymnostoma species were exposed to a drying climate, trichomes developed in the base of the furrows and the stomatal bands migrated from the external surface to the walls of the furrows (old adaxial leaf surface). This is characteristic of the extant Ceuthostoma species and is a xeromorphic response. $(g)$ As the climate continued to dry, the number of phyllichnia per article increased from four to five, which allows for a rounder article section and furrows that can be closed off at the surface more effectively. This is a further xeromorphic response. (h) Finally, the number of phyllichnia per article increased to much larger numbers, leading to the arrangement seen in many extant Allocasuarina and Casuarina species. The extra phyllichnia leads to a rounded article in section and to extremely high levels of protection of the stomata within the furrows. This is an extreme xeromorphic response.

(McCoy 1998; Prider and Christophel 2000). However, Gymnostoma does dominate some complex forests in New Caledonia (McCoy 1998) and Prider and Christophel (2000) note that although $G$. australianum does not occur where light is limiting, it is not a coloniser of disturbed habitats, but is best described as a habitat specialist, occurring in marginal, low nutrient sites within various types of rainforest.

Soon after the appearance of the first Gymnostoma macrofossils, in the Early Eocene, the world entered a period of extremely high temperatures, with high rainfall and humidity, with dense cloud cover at high latitudes (Sagoo et al. 2013; Loptson et al. 2014), which is where Australia was placed at the time. Although Gymnostoma may be limited to relatively high-light environments today, the combination of high latitude (and hence low sun angles in the sky), high cloud cover, and species-rich rainforests, meant that Gymnostoma, which is common in the macrofossil record of southern Australia during the Eocene, must have survived under light levels that would be considered as relatively low today.

It has been well established that the likely first member of the Casuarinaceae had leaves in whorls of four, and that the closest living relative is Gymnostoma. However, little else has been resolved regarding the way in which the early members of this family may have evolved. If we assume that the precursor of Casuarinaceae had leaves that were free and spreading from the stem, it is reasonable to assume that they may have had stomata on the abaxial leaf surface, as is the case for many angiosperms today. As these leaves became appressed to the main axis of the stem, these stomates would have been on the surface facing away from the main axis (e.g. Fig. 9a). Presumably these leaves then fused to the main axis for almost their entire length and in doing so, the furrows that now characterise many Casuarinaceae articles would simply represent the spaces between adjacent fused leaves and their bases (Fig. 9b), with stomates in bands on the outer surface, on either side of the midvein. This is almost exactly the arrangement of the articles of most fossil and living Gymnostoma species (Fig. 9c). We propose that this is the likely form of the first species of the Casuarinaceae, which evolved scleromorphy in response to phosphorus-poor soils. However, it is not known why this should result in leaf fusion to the main axis.

We hypothesise that the Eocene species of Gymnostoma evolved in at least two different directions, depending on water 
availability. For species growing in the extremely wet and relatively low-light environments of the Eocene, the major pressure would have been to maximise the potential photosynthetic area, thereby allowing the plants to have the highest possible growth rates in the species-rich rainforests in which they grew. To do this, the furrows disappeared and the articles took on the square shape in section that characterises some fossil and living Gymnostoma species (Fig. 9d), thereby positioning the stomata where the boundary layer is minimal (allowing relatively rapid gas exchange) and the maximum leaf area is available for photosynthesis. This morphology is common in mid-Eocene specimens and apparently occurs in all 300 fossil branchlets examined by Christophel (1980) from Anglesea, and the smaller number of fossil branchlets recovered from Nerriga and Maslin Bay (Fig. 5).

Another selection pressure was the drying of the climate from the Oligocene onwards. The response to this was to migrate the stomata to the inside of the already existing grooves of early Gymnostoma species, thereby increasing the boundary layer and reducing water loss through the stomata. The development of trichomes within the furrows would have further increased the effectiveness of the boundary layer. This has been noted in living Callitris columellaris (Cupressaceae), which has a remarkably similar leaf morphology to some Casuarinaceae. Attiwill and ClaytonGreene (1984) note that the stomata of these species are in furrows between decurrent leaves and that when subjected to severe drought these furrows close, apparently stopping gas exchange (including transpiration) almost completely.

Ceuthostoma has not been recorded in the fossil record, but possibly represents an early stage in this process (Fig. 9f). Nevertheless, it is also possible that this genus followed a different strategy. For example, Pariyar et al. (2017) note that apparent xeromorphic traits can sometimes be advantageous in maintaining photosynthesis in wet environments. They give the example of a Chamaecyparis (Cupressaceae) species growing in conditions where a substantial water film forms on branchlets. By clustering the stomata within narrow clefts the species avoids having water cover the stomatal openings, hence preventing $\mathrm{CO}_{2}$ uptake. The presence of florin rings around the stomata may also assist in keeping water out of stomatal openings, and at least some Casuarinaceae species have structures similar in form to florin rings (e.g. Fig. $8 e, f$ ). More research is required to determine the evolutionary pressures that led to the evolution of Ceuthostoma. The possibility that its morphology reflects a mesomorphic response is not shown in Fig. 9.

As climates became increasingly drier, the next evolutionary transition was to increase the number of leaves per whorl. This changed the overall shape of the article to round in section and, more importantly, allowed for the evolution of furrows with a narrower opening (Johnson and Wilson 1989), thus strongly protecting the stomates within them from water loss (Fig. $9 g, h$ ). It is significant that the earliest examples in the fossil record of non-Gymnostoma Casuarinaceae are recorded as an Early Miocene Casuarina species with four teeth per whorl (D. T. Blackburn, unpubl. data) and the probable Oligocene Cryptostomiforma quinta, which usually has five, but sometimes four teeth per whorl (Guerin and Hill 2006). There is one more quite speculative hypothesis about Casuarinaceae evolution. Some living Gymnostoma species have an unusual shape in section, where there is a uniformly angled curve between the phyllichnia with the stomates at the deepest point (e.g. Fig. 4b). We propose that this might be the evolutionary response of species that had achieved the square sectional shape shown in Fig. $9 d$ and Fig. $7 d$, e, and hence, had completely lost the furrow, but were later exposed to water stress and evolved morphologically to increase the boundary layer above the stomates. Because the furrow had disappeared, it may be that these species had lost the capacity to 're-evolve' a narrow furrow, and they responded by producing a furrow that was nearly the entire width between the high points of the phyllichnia (Fig. $4 b \mathrm{cf}$. Fig. $4 a$ ). This morphology appears to occur in several extant Gymnostoma species in both of the clades identified by Steane et al. (2003), suggesting that this strategy evolved more than once within the genus.

The encryption of stomata by various means has long been regarded as a xeromorphic trait, providing control and reduction of transpiration and hence overall water loss (e.g. Hassiotou et al. 2009). However, recent research has shown that these characters also occur in species that inhabit environments with high humidity and precipitation (Jordan et al. 2005; Pariyar et al. 2017; see earlier in this section). This has led to significant re-evaluation of the role of stomatal encryption, and the contrary demands of desiccation avoidance and carbon dioxide uptake for photosynthesis. Several potential roles have been suggested for stomatal encryption (Haworth and McElwain 2008), including protection against pathogenic fungi, bacteria, herbivorous animals and airborne dust (e.g. Glover 2000; Peeters 2002; Bargel et al. 2004). More recently, Roth-Nebelsick et al. (2009) suggested it is unlikely that the primary function of stomatal crypts is to reduce transpiration, and that deep invagination of crypts into the mesophyll may facilitate carbon dioxide diffusion. Their research was conducted on leaves with a broad lamina, containing stomatal crypts on the abaxial leaf surface. The conclusion is that encryption of stomata within the leaves reduces the amount of leaf tissue that the carbon dioxide needs to traverse to reach the major site of photosynthesis in the chloroplast rich cells near the adaxial (upper) leaf surface, i.e. closest to the source of energy (solar radiation).

Although this is an interesting hypothesis that requires further research, the suggestion that encryption decreases the distance that carbon dioxide molecules need to travel from the stomata to the main density of chloroplasts clearly does not apply in the Casuarinaceae. Here, stomata in deep furrows apparently increases the distance that carbon dioxide must travel within the leaf in order to reach the site of photosynthesis (i.e. from deep within a furrow to cells near the surface of a phyllichnium) and hence some other selective pressure must have driven this morphology. More physiological research is required to resolve this issue, but our conclusion is that the placement of stomata in furrows in the Casuarinaceae is extremely likely to have been primarily a xeromorphic adaptation. 


\section{Evidence from the pollen record}

The fossil pollen record can be used to examine broad changes in the vegetation through time, to determine whether this is consistent with changes inferred from the macrofossil record of individual taxa. The taxonomic affinities of Casuarinaceae pollen cannot be determined beyond the family level (Kershaw et al. 1994; Macphail et al. 1994). As such, the nature and ecology of Casuarinaceae, including whether the fossil pollen represents rainforest (Gymnostoma) or xeromorphic (Ceuthostoma?-Allocasuarina-Casuarina) species, can be inferred only after considering the associated species (Macphail et al. 1994) and more often, using macrofossil evidence. In the Cenozoic palynofloral record, Casuarinaceae pollen is represented by the species Haloragacidites harrisii (Couper) Harris and Casuarinidites cainozoicus Cookson \& Pike.

After first appearing in the Paleocene of Australia (Stover and Partridge 1973), the wind-pollinated Casuarinaceae evolved from a minor element of the palynoflora (Truswell 1993; Macphail et al. 1994; Martin 1994), to one of the most prolific taxa in Australian Cenozoic palynofloral records. In Early and Middle Eocene pollen assemblages, Casuarinaceae pollen is represented by low to moderate abundances respectively throughout Australia (Macphail et al. 1994; Martin 1994; Partridge and Dettmann 2003; Korasidis et al. 2019a). In the Early and Middle Eocene, Casuarinaceae pollen is associated with high relative abundances of Proteaceae, numerous thermophyllous angiosperms (i.e. Austrobuxus, Cupanieae), podocarps and low relative abundances of Nothofagus, consistent with megathermal rainforests representing the dominant vegetation (Macphail et al. 1994; Martin 1994; Partridge and Dettmann 2003; Korasidis et al. 2019a). In Late Eocene pollen assemblages, Casuarinaceae pollen is abundant and associated with high relative abundances of Nothofagus (Subgenus Brassospora) and podocarps due to increasingly cooler temperatures and mesothermal rainforest development (Macphail et al. 1994; Martin 1994; Macphail 1999; Korasidis et al. 2019a). As such, Casuarinaceae pollen in Paleocene and Eocene palynofloral assemblages in Australia are interpreted to represent the rainforest genus Gymnostoma (Macphail et al. 1994), which is consistent with the macrofossil record.

In the Oligocene and Early Miocene, in pollen assemblages throughout eastern Australia, Casuarinaceae occurs in relatively low abundances (Truswell 1993; Macphail et al. 1994; Korasidis et al. 2019a). During the Oligocene and Early Miocene, Casuarinaceae pollen is associated with high relative abundances of Nothofagus (Subgenus Brassospora) and moderate abundances of southern conifer (e.g. Araucariacites spp., Dacrycarpidites spp.) and Myrtaceae pollen (Kershaw 1988; Martin 1994; Macphail 1999; Korasidis et al. 2016, 2017). This affiliation is consistent with cool-temperate rainforest development in south-eastern Australia during the Oligocene and Early Miocene (Korasidis et al. 2019a). Elsewhere in Australia, i.e. in the North West shelf and Murray Basin, Casuarinaceae pollen is of high abundance throughout the Oligocene and Early Miocene associated with the establishment of marginal marine depositional settings (Martin 1990, 1994; Martin and McMinn 1994). In the Middle Miocene, Casuarinaceae pollen is also of relatively moderate abundance throughout eastern Australia, where it is associated with high relative abundances of southern conifer (i.e. Phyllocladidites) and low abundances of Nothofagus (Subgenus Brassospora) pollen, consistent with the development of warm temperate rainforests (Macphail 1999; Korasidis et al. 2019a). As such, Casuarinaceae pollen during the Oligocene and Early-Middle Miocene palynological assemblages are also interpreted to represent the rainforest genus Gymnostoma.

Notably, many elements in Australia's modern opencanopied flora (i.e. Eucalyptus, Amaranthaceae, Acacia, Asteraceae and Poaceae) are present in Oligocene and EarlyMiddle Miocene palynofloral assemblages, but only in very low quantities (Kershaw et al. 1994; Macphail et al. 1994; Martin 1994). Moreover, recent works (Korasidis et al. 2016, 2019b) have argued against earlier suggestions that sclerophyllous communities increased in abundance within the Middle Miocene brown coals of the Latrobe Valley (i.e. Sluiter and Kershaw 1982; Kershaw et al. 1994), and instead concluded that modern sclerophyllous elements are best represented in the low nutrient and fire-prone environments that fringed the ever-wet rainforests of the Latrobe Valley. These palynological observations therefore suggest that any open vegetation was extremely restricted, if present, before the Late Miocene in south-eastern Australia. However, xeromorphic Casuarinaceae macrofossils are present, although relatively rare) in the Morwell and Yallourn Open Cut Coal Mines (D. T. Blackburn, unpubl. data), so the vegetation reconstruction of these coals is not yet complete.

Recently, Macphail and Hill (2018), in summarising the likely vegetation in north-west Australia during the Paleogene, found that Casuarinaceae was the dominant woody taxon, with the older Casuarinaceae communities (Paleocene-Eocene) being difficult to interpret, with speculation that they may have been a form of monsoon rainforest and grew in a climate that in part supported the evolution of xeromorphic adaptations (i.e. the transition from Gymnostoma to Allocasuarina-Casuarina). However, during the Oligocene to possibly Early Miocene the vegetation near their sampling site was 'Casuarinaceae sclerophyll forest or woodland growing under seasonally dry conditions and related to modern Allocasuarina-Casuarina formations'. This is supported to by the presence of Cryptostomiforma quinata macrofossils from the probable Oligocene of the Riversleigh location, where the vegetation was interpreted as sclerophyllous and deciduous vine thickets with at least seasonal moisture limitation (Guerin and Hill 2006).

In the Late Miocene and Pliocene palynofloral assemblages, Casuarinaceae pollen has relatively high abundance throughout Australia (Macphail 1999; Partridge and Dettmann 2003). Late Miocene and Pliocene pollen records also contain the first unequivocal evidence for open sclerophyll vegetation with Casuarinaceae, Myrtaceae (Eucalyptus), Asteraceae, Poaceae and Amaranthaceae becoming increasingly more common as a result of increasingly drier conditions over Australia (Kershaw 1988; 
Kershaw et al. 1994; Martin 1990, 1994, 2006; Macphail 1997). Notably, this sclerophyll vegetation is associated with a high diversity of rainforest taxa albeit of relatively low abundance (i.e. Dacrydium, Podocarpus, Phyllocladus and Nothofagus; Kershaw 1988; Martin 1990, 1994, 2006; Kershaw et al. 1994). As such, Casuarinaceae pollen during the Late Miocene and Pliocene is generally interpreted as being derived from the modern Australian sclerophyllous (Allocasuarina-Casuarina) species, which are common elements of open sclerophyll vegetation today.

\section{Conclusion}

The Casuarinaceae has long been recognised as an important Gondwanan family, but very little is known about its ancestors or the way in which it evolved into such an unusual vegetative form. The macrofossil record is slowly providing evidence for how the family may have evolved after its first appearance, but the initial stages in the evolution of this family remain elusive. However, extensive research on both the living and fossil members of the family provides enough information to propose a set of hypotheses about the evolution of the family (Fig. 9). In summary, we hypothesise that the main evolutionary drivers of Casuarinaceae may have been:

(1) a scleromorphic response in relatively open vegetation, leading to an ancestor with Gymnostoma-like foliage, with leaves mostly fused to the main axis, deep furrows between adjacent leaves and stomata in exposed bands on the outer surface. The early evolution of Gymnostoma (no later than Late Paleocene) means that the remaining conclusions are based on changes to the morphology of vegetative structures in that genus;

(2) a mesomorphic response in Gymnostoma that led to loss of the furrows as the wet and shady Eocene environments meant that the articles evolved to maximise their photosynthetic area. This may have occurred more than once within the genus;

(3) a minor xeromorphic response in Gymnostoma as the climate dried, leading to wide depressions between the ridges of phyllichnia with stomatal bands deep within them, increasing the boundary layer. Again, this may have occurred more than once within the genus; and

(4) a major xeromorphic response leading to the evolution of Ceuthostoma, and then possibly later Allocasuarina and Casuarina, where the stomatal bands migrated to within the furrows, which filled with complex trichomes, and then the number of articles per whorl increased to maximise the impact of the furrows in increasing the boundary layer and decreasing water loss. The possibility exists that Ceuthostoma may have evolved under extremely wet conditions, but this cannot be resolved without more detailed understanding of its modern ecology and morphology.

There are some unusual features of the history of the Casuarinaceae that should be highlighted.

(1) The macrofossil record is usually restricted to wet environments, and so the likelihood of finding fossils that preserve key information on evolution in response to drying conditions is relatively low. However, there are good non-Gymnostoma macrofossils in Australia that do demonstrate consistent evidence for the way in which evolution may have taken place.

(2) There are some important and well-studied sites where Casuarinaceae macrofossils have not been recorded. These include Lea River (Early Oligocene), Monpeelyata (Late Oligocene-Early Miocene) and Pioneer (Early Miocene) in Tasmania, all of which represent vegetation growing in wet but relatively cold conditions. The absence of Casuarinaceae at these sites may indicate an ecological niche that the family could not fill.

(3) There is clear evidence for the overlap of Gymnostoma and non-Gymnostoma fossils in Australia circa the Oligocene-Miocene. This is an important area for future research. Unfortunately, known macrofossil localities for this time span are relatively poorly dated.

(4) At present no reliable data allow the morphological separation of branchlets of Allocasuarina from Casuarina and so the fossil record of vegetative material of these two genera cannot be distinguished at generic level.

A great deal of research remains to be undertaken on the fossil record of this important family, but it is clear that it is a key taxon in understanding the evolution of the Australian vegetation as the climate dried from the mid-Cenozoic. More complex interpretations of the evidence presented here are possible and there is a great deal of scope for future research to better understand the evolution of this key family in the Australian vegetation.

\section{Conflicts of interest}

Robert S. Hill is the Guest Editor of the 'Dry adapted vegetation' special issue. Despite this relationship, he did not at any stage have Editor-level access to this manuscript or any other manuscript in this issue that he authored, as is the standard practice when handling manuscripts submitted by an editor to this journal. Australian Journal of Botany encourages its editors to publish in the journal and they are kept totally separate from the decision-making process for their manuscripts. The author is also an author of one other paper in this special issue. The author has no further conflicts of interest to declare.

\section{Funding statement}

This research did not receive any specific funding.

\section{Acknowledgements}

This work is the result of decades of separate research projects, supported by several grants from the Australian Research Council. We thank the many people who have contributed to discussions of the evolution of the Casuarinaceae over a long time.

\section{References}

Attiwill PM, Clayton-Greene KA (1984) Studies of gas exchange and development in a subhumid woodland. Journal of Ecology 72, 285-294. doi: $10.2307 / 2260020$ 
Bargel H, Barthlott W, Koch K, Schreiber L, Neinhuis C (2004) Plant cuticles: multifunctional interfaces between plant and environment. In 'The Evolution of Plant Physiology' (Eds AR Hemsley, I Poole) Linnean Society Symposium Series number 21, pp. 171-194. (Elsevier: London, UK)

Burrows GE (2001) Comparative anatomy of the photosynthetic organs of 39 xeromorphic species from subhumid New South Wales, Australia. International Journal of Plant Sciences 162, 411-430. doi: $10.1086 / 319579$

Callen RA (2020) Neogene Billa Kalina Basin and Stuart Creek silicified floras, northern South Australia: a reassessment of their stratigraphy, age and environments. Australian Journal of Earth Sciences doi:10.1080/08120099.2020.1736630

Carpenter RJ, Pole MS (1995) Eocene plant fossils from the Lefroy and Cowan paleodrainages, Western Australia. Australian Systematic Botany 8, 1107-1154. doi:10.1071/SB9951107

Carpenter RJ, Hill RS, Greenwood DR, Partridge AD, Banks MA (2004) No snow in the mountains: Early Eocene plant fossils from Hotham Heights, Victoria, Australia. Australian Journal of Botany 52, 685-718. doi:10.1071/BT04032

Carpenter RJ, Macphail MK, Jordan GJ, Hill RS (2015) Fossil evidence for open, Proteaceae-dominated heathlands and fire in the Late Cretaceous of Australia. American Journal of Botany 102, 2092-2107. doi:10.3732/ajb.1500343

Christophel DC (1980) Occurrence of Casuarina megafossils in the Tertiary of south-eastern Australia. Australian Journal of Botany 28, 249-259. doi:10.1071/BT9800249

Christophel DC, Greenwood DR (1987) A megafossil flora from the Eocene of Golden Grove, South Australia. Transactions of the Royal Society of South Australia 111, 155-162.

Christophel DC, Scriven LJ, Greenwood DR (1992) An Eocene megafossil flora from Nelly Creek, South Australia. Transactions of the Royal Society of South Australia 116, 65-76.

Dettmann ME (1994) Cretaceous vegetation: the microfossil record. In 'History of the Australian Vegetation: Cretaceous to Recent.' (Ed. RS Hill) pp. 143-170. (Cambridge University Press: Cambridge, UK)

Dörken VM, Parsons RF (2017) Morpho-anatomical studies on the leaf reduction in Casuarina: the ecology of xeromorphy. Trees 31 , 1165-1177. doi:10.1007/s00468-017-1535-5

Dörken VM, Parsons RF, Ladd PG (2018) The foliar change from seedlings to adults in Allocasuarina (Casuarinaceae): the evolutionary and ecological aspects of leaf reduction, xeromorphy and scleromorphy. Feddes Repertorium 129, 193-222. doi:10.1002/fedr.201800004

Dörken VM, Ladd PG, Parsons RF (2019) Foliar ontogeny in Gymnostoma deplancheanum and its evolutionary and ecological significance for scleromorphy and xeromorphy in Casuarinaceae (Fagales). Trees 33, 653-668. doi:10.1007/s00468-018-1806-9

Douglas JG (1978) Victoria's oldest flowers. Victorian Naturalist 95, $137-140$

Erdtman G (1966) 'Pollen Morphology and Plant Taxonomy Angiosperms.' (Hafner: New York, NY, USA)

Flores EM (1977) Developmental studies in Casuarina (Casuarinaceae). III. The anatomy of the mature branchlet. Revista de Biología Tropical 25, 65-87.

Flores EM (1980) Shoot vascular system and phyllotaxis of Casuarina (Casuarinaceae). American Journal of Botany 67, 131-140. doi:10.1002/j.1537-2197.1980.tb07634.x

Glover BJ (2000) Differentiation in plant epidermal cells. Journal of Experimental Botany 51, 497-505. doi:10.1093/jexbot/51.344.497

Guerin G, Hill RS (2003) Gymnostoma tasmanianum sp. nov., a fossil Casuarinaceae from the Early Oligocene of Little Rapid River, Tasmania, Australia. International Journal of Plant Sciences 164, 629-634. doi: $10.1086 / 375375$
Guerin GR, Hill RS (2006) Plant macrofossil evidence for the environment associated with the Riversleigh fauna. Australian Journal of Botany 54, 717-731. doi:10.1071/BT04220

Hassiotou F, Evans JR, Ludwig M, Veneklaas EJ (2009) Stomatal crypts may facilitate diffusion of $\mathrm{CO}_{2}$ to adaxial mesophyll cells in thick sclerophylls. Plant, Cell \& Environment 32, 1596-1611. doi:10.1111/j.1365-3040.2009.02024.x

Haworth M, McElwain J (2008) Hot, dry, wet, cold or toxic? Revisiting the ecological significance of leaf and cuticular micromorphology. Palaeogeography, Palaeoclimatology, Palaeoecology 262, 79-90. doi:10.1016/j.palaeo.2008.02.009

Hekel H (1972) Pollen and spore assemblages from Queensland Tertiary sediments. Publication number 355, Palaeontological papers number 30, Geological Survey of Queensland, Brisbane, Qld, Australia.

Hill RS (1982) The Eocene megafossil flora of Nerriga, New South Wales, Australia. Palaeontographica. Abteilung B, Paläophytologie 181, 44-77.

Hill RS (1990) The fossil history of Tasmania's rainforest tree species. Tasforests 2, 5-12.

Hill RS (1994) The history of selected Australian taxa. In 'History of the Australian Vegetation: Cretaceous to Recent.' (Ed. RS Hill) pp. 390-419. (Cambridge University Press: Cambridge, UK)

Hill RS (1998) Fossil evidence for the onset of xeromorphy and scleromorphy in Australian Proteaceae. Australian Systematic Botany 11, 391-400. doi:10.1071/SB97016

Hill RS (2001) Nothofagus cupules from Oligocene-Early Miocene sediments at Balfour, north-west Tasmania, Australia. International Journal of Plant Sciences 162, 683-690. doi:10.1086/320140

Hill RS, Brodribb TJ (2001) Macrofossil evidence for the onset of xeromorphy in Australian Casuarinaceae and tribe Banksieae (Proteaceae). Journal of Mediterranean Ecology 2, 127-136.

Hill RS, Merrifield HE (1993) An Early Tertiary macroflora from West Dale, southwestern Australia. Alcheringa 17, 285-326. doi: $10.1080 / 03115519308619596$

Hwang YH (1989) The Casuarinaceae: the closest taxon to the family. Australian Systematic Botany Society Newsletter 61, 2-3.

Johnson LAS, Wilson KL (1989) Casuarinaceae: a synopsis. In 'Evolution, Systematics, and Fossil History of the Hamamelidae. Vol. 2: Higher Hamamelidae'. Eds PR Crane, S Blackmore) pp. 167-188. (Clarendon Press: Oxford, UK)

Jordan GJ, Dillon RA, Weston PH (2005) Solar radiation as a factor in the evolution of scleromorphic leaf anatomy in Proteaceae. American Journal of Botany 92, 789-796. doi:10.3732/ajb.92.5.789

Kershaw AP (1988) Australasia. In 'Vegetation History'. (Eds B Huntley, T Webb III) pp. 237-306. (Kluwer: Dordrecht, Netherlands)

Kershaw AP, Martin HA, Mason JM (1994) The Neogene: a period of transition. In 'History of the Australian Vegetation: Cretaceous to Recent'. (Ed. RS Hill) pp. 299-327. (Cambridge University Press: Cambridge, UK)

Korasidis VA, Wallace MW, Wagstaff BE, Holdgate GR, Tosolini A-MP, Jansen B (2016) Cyclic floral succession and fire in a Cenozoic wetland/peatland system. Palaeogeography, Palaeoclimatology, Palaeoecology 461, 237-252. doi:10.1016/j.palaeo.2016.08.030

Korasidis VA, Wallace MW, Wagstaff BE, Holdgate GR (2017) OligoMiocene peatland ecosystems of the Gippsland Basin and modern analogues. Global and Planetary Change 149, 91-104. doi:10.1016/j.gloplacha.2017.01.003

Korasidis VA, Wallace MW, Wagstaff BE, Hill RS (2019a) Terrestrial cooling record through the Eocene-Oligocene transition of Australia. Global and Planetary Change 173, 61-72. doi:10.1016/j.gloplacha.2018.12.007

Korasidis VA, Wallace MW, Wagstaff BE, Hill RS (2019b) Evidence of early fire adaption in Australian Cenozoic rainforests. Palaeogeography, Palaeoclimatology, Palaeoecology 516, 35-43. doi:10.1016/j.palaeo.2018.11.023 
Lange RT (1970) The Maslin Bay flora, South Australia. 2. The assemblage of fossils. Neues Jahrbuch für Geologie und Paläontologie 8, 486-490.

Loptson CA, Lunt DJ, Francis JE (2014) Investigating vegetation-climate feedbacks during the early Eocene. Climate of the Past 10, 419-436. doi:10.5194/cp-10-419-2014

Macphail M (1997) Late Neogene climates in Australia: fossil pollen-and spore-based estimates in retrospect and prospect. Australian Journal of Botany 45, 425-464. doi:10.1071/BT96052

Macphail M (1999) Palynostratigraphy of the Murray Basin, inland southeastern Australia. Palynology 23, 197-240. doi:10.1080/01916122.1999.9989528

Macphail MK, Hill RS (2018) What was the vegetation in northwest Australia during the Paleogene, 60-23 million years ago? Australian Journal of Botany 66, 556-574. doi:10.1071/BT18143

Macphail MK, Alley NF, Truswell EM, Sluiter IRK (1994) Early Tertiary vegetation: evidence from spores and pollen. In 'History of the Australian Vegetation: Cretaceous to Recent'. (Ed. RS Hill) pp. 189-261. (Cambridge University Press: Cambridge, UK)

Manos PS, Steele KP (1997) Phylogenetic analyses of 'higher' Hamamelididae based on plastid sequence data. American Journal of Botany 84, 1407-1419. doi:10.2307/2446139

Martin HA (1990) Tertiary climate and phytogeography in southeastern Australia. Review of Palaeobotany and Palynology 65, 47-55. doi:10.1016/0034-6667(90)90055-N

Martin H (1994) Australian Tertiary phytogeography: evidence from palynology. In 'History of the Australian Vegetation: Cretaceous to Recent'. (Ed. RS Hill) pp. 104-142. (Cambridge University Press: Cambridge, UK)

Martin H (2006) Cenozoic climatic change and the development of the arid vegetation in Australia. Journal of Arid Environments 66, 533-563. doi:10.1016/j.jaridenv.2006.01.009

Martin HA, McMinn A (1994) Late Cainozoic vegetation history of northwestern Australia, from the palynology of a deep sea core (ODP Site 765). Australian Journal of Botany 42, 95-102. doi:10.1071/BT9940095

McCoy SG (1998) The dynamics of Gymnostoma maquis on ultramafic soils in New Caledonia. PhD thesis, Department of Archaeology and Natural History, Australian National University, Canberra, ACT, Australia.

McLoughlin S, Hill RS (1996) The succession of Western Australian Phanerozoic terrestrial floras. In 'Gondwanan Heritage: Past, Present and Future of the Western Australian Biota'. (Eds SD Hopper, JA Chappill, MS Harvey, AS George) pp. 61-80. (Surrey Beatty \& Sons: Sydney, NSW, Australia)

Morini F (1895) Contributo all'anatomia del caule e della foglia delle Casuarina. Memoirie II. Memorie della Reale Accademia della Scienze dell' Instituto di Bologna 5, 555-615.

Niinemets Ü, Lukjanova A, Sparrow AD, Turnbull MH (2005) Light acclimation of cladode photosynthetic potentials in Casuarina glauca: trade-offs between physiological and structural investments. Functional Plant Biology 32, 571-582. doi:10.1071/FP05037

Pariyar S, Chang S-C, Zinsmeister D, Zhou H, Grantz DA, Hunsche M, Burkhardt J (2017) Xeromorphic traits help to maintain photosynthesis in the perhumid climate of a Taiwanese cloud forest. Oecologia 184, 609-621. doi:10.1007/s00442-017-3894-4

Partridge A, Dettmann M (2003) Plant microfossils. Special Publication (Geological Society of Australia) 23, 639-652.

Patton RT (1936) A fossil Casuarina. Proceedings of the Royal Society of Victoria 49, 36-39.
Peeters PJ (2002) Correlations between leaf structural traits and the densities of herbivorous insect guilds. Biological Journal of the Linnean Society. Linnean Society of London 77, 43-65. doi:10.1046/j.1095-8312.2002.00091.x

Pike KM (1953) Fossil fruiting cones of Casuarina and Banksia from Tertiary deposits in Victoria. Papers and Proceedings of the Royal Society of Victoria 65, 1-8.

Pole MS (1992) Eocene vegetation from Hasties, north-eastern Tasmania. Australian Systematic Botany 5, 431-475. doi:10.1071/SB9920431

Pole MS (1998) Early Eocene estuary at Strahan, Tasmania. Australian Journal of Earth Sciences 45, 979-985. doi:10.1080/08120099808728452

Pole MS, Hill RS, Green N, Macphail MK (1993) The Late Oligocene Berwick Quarry flora - rainforest in a drying environment. Australian Systematic Botany 6, 399-427. doi:10.1071/SB9930399

Prider JN, Christophel DC (2000) Distributional ecology of Gymnostoma australianum (Casuarinaceae), a putative palaeoendemic of Australian wet tropic forests. Australian Journal of Botany 48, 427-434. doi:10.1071/BT99006

Qiu YL, Chase MW, Hoot SB, Conti E, Crane PR, Sytsma KJ, Parks CR (1998) Phylogenetics of the Hamamelidae and their allies: parsimony analyses of nucleotide sequences of the plastid gene $r b c \mathrm{~L}$. International Journal of Plant Sciences 159, 891-905. doi:10.1086/314084

Rao AN (1972) Anatomical studies on succulent cladodes in Casuarina equisetifolia L. Proceedings of the Indiana Academy of Sciences 86, 262-270.

Roth-Nebelsick A, Hassiotou F, Veneklaas EJ (2009) Stomatal crypts have small effects on transpiration: A numerical model analysis. Plant Physiology 151, 2018-2027. doi:10.1104/pp.109.146969

Sagoo N, Valdes P, Flecker R, Gregoire LJ (2013) The Early Eocene equable climate problem: can perturbations of climate model parameters identify possible solutions? Philosophical Transactions of the Royal Society of London - A. Mathematical and Physical Sciences 371, 20130123. doi:10.1098/rsta.2013.0123

Scriven LJ, Christophel DC (1990) A numerical taxonomic study of extant and fossil Gymnostoma. In 'Proceedings, 3IOP Conference', 24-26 August 1988, Melbourne, Vic., Australia. (Eds JG Douglas, DC Christophel) pp. 137-147. (A-Z Printers: Melbourne, Vic., Australia)

Scriven LJ, Hill RS (1995) Macrofossil Casuarinaceae: their identification and the oldest macrofossil record, Gymnostoma antiquum sp. nov., from the Late Paleocene of New South Wales, Australia. Australian Systematic Botany 8, 1035-1053. doi:10.1071/SB9951035

Sluiter IR, Kershaw AP (1982) The nature of Late Tertiary vegetation in Australia. Alcheringa 6, 211-222. doi:10.1080/03115518208565414

Sogo A, Setoguchi H, Noguchi J, Jaffré T, Tobe H (2001) Molecular phylogeny of Casuarinaceae based on $r b c L$ and matK gene sequences. Journal of Plant Research 114, 459-464. doi:10.1007/PL00014011

Steane DA, Wilson KL, Hill RS (2003) Using matK sequence data to unravel the phylogeny of Casuarinaceae. Molecular Phylogenetics and Evolution 28, 47-59. doi:10.1016/S1055-7903(03)00028-9

Stover L, Partridge A (1973) Tertiary and Late Cretaceous spores and pollen from the Gippsland Basin, southeastern Australia. Proceedings of the Royal Society of Victoria 85, 237-286.

Torrey JG, Berg RH (1988) Some morphological features for generic characterization among the Casuarinaceae. American Journal of Botany 75, 864-874. doi:10.1002/j.1537-2197.1988.tb13510.x

Truswell E (1993) Vegetation in the Australian Tertiary in response to climatic and phytogeographic forcing factors. Australian Systematic Botany 6, 533-557. doi:10.1071/SB9930533 
Ueno J (1963) On the fine structure of the pollen walls of angiospermae. III. Casuarina. Grana Palynologica 4, 189-194. doi: $10.1080 / 00173136309436741$

Warrier KCS, Suganthi A, Singh BG (2013) A new record of abnormal phylloclade modification in Casuarina equisetifolia International International Journal of Agricultural Science Research 2, 8-11.

Wodehouse RP (1959) 'Pollen Grains: Their Structure, Identification, and Significance in Science and Medicine.' (Hafner: New York, NY, USA)

Xiang XG, Wang W, Li RQ, Lin L, Liu Y, Zhou ZK, Li ZY, Chen ZD (2014) Large-scale phylogenetic analyses reveal fagalean diversification promoted by the interplay of diaspores and environments in the Paleogene. Perspectives in Plant Ecology, Evolution and Systematics 16, 101-110. doi:10.1016/j.ppees.2014.03.001
Zimpfer JF, Igual JM, McCarty B, Smyth C, Dawson JO (2004) Casuarina cunninghamiana tissue extracts stimulate the growth of Frankia and differentially alter the growth of other soil microorganisms. Journal of Chemical Ecology 30, 439-452.

doi:10.1023/B:JOEC.0000017987.19225.86

Handling editor: Olusegun Osunkoya 


\section{University Library}

\section{- M M N E R VA A gateway to Melbourne's research publications}

Minerva Access is the Institutional Repository of The University of Melbourne

Author/s:

Hill, RS;Whang, SS;Korasidis, V;Bianco, B;Hill, KE;Paull, R;Guerin, GR

Title:

Fossil evidence for the evolution of the Casuarinaceae in response to low soil nutrients and a drying climate in Cenozoic Australia

Date:

2020

Citation:

Hill, R. S., Whang, S. S., Korasidis, V., Bianco, B., Hill, K. E., Paull, R. \& Guerin, G. R. (2020). Fossil evidence for the evolution of the Casuarinaceae in response to low soil nutrients and a drying climate in Cenozoic Australia. Australian Journal of Botany, 68 (3), pp.179-194. https://doi.org/10.1071/bt19126.

Persistent Link:

http://hdl.handle.net/11343/293066 